\title{
Critical Discourse Studies
}

\section{Marx's critique of ideology for discourse analysis: from analysis of ideologies to social critique}

\section{Benno Herzog}

To cite this article: Benno Herzog (2018): Marx's critique of ideology for discourse analysis: from analysis of ideologies to social critique, Critical Discourse Studies, DOI: 10.1080/17405904.2018.1457549

To link to this article: https://doi.org/10.1080/17405904.2018.1457549

曲 Published online: 29 Mar 2018.

Submit your article to this journal $\asymp$

山 Article views: 22

Q View related articles $\sqsubset$

View Crossmark data $₫$ 


\title{
Marx's critique of ideology for discourse analysis: from analysis of ideologies to social critique
}

\author{
Benno Herzog \\ Department of Sociology and Social Anthropology, University of Valencia, València, Spain
}

\begin{abstract}
The notion of ideology is related to social and material reality and especially to the processes of social reproduction. Therefore, the analysis of ideology seems to fall into the domain of discourse analysis. The analysis of language and practices of signification in social contexts constitutes the basic triangle of discourse analysis. However, the Marxist concept of ideology always refers to some kind of falsity, that ultimately enables the researcher to not only analyse but also to criticize ideologies. Ideologies are always in some way false, injust or inadequate. It is at this point that discourse analysts usually raise the most serious objections as they understand truth itself as a discursive product, resulting from powerful struggles of domination and exclusion. The present article explores in how far the Marxist notion can be used for the purpose of discourse analysis. It argues that even the notion of falsity as present in classical Marxism can be adapted for understanding and criticizing contemporary ideologies. I start by presenting some common understandings of ideology in the field of Discourse Studies (I). In a second step I will analyse elements of the notion of ideology in Marx's early writings, especially in the debate with the Young Hegelians (II) and ask what this means for empirical discourse analysis. I will then point towards elements of the critique of ideology in Marx mature 'political economy' that could be fruitful for Discourse Studies (III). Finally, I will try to reconcile a Marxist concept of ideology based ultimately on a notion of falsity with such discourse analytical approaches highly suspicious of the possibility of the existing 'politics of truth' (IV). We will see that, due to the relation between ideas and material organization in ideologies, the critique of ideologies becomes not only a critique of practices of justifications but turns into a genuine social critique.
\end{abstract}

\section{ARTICLE HISTORY}

Received 30 August 2017

Accepted 21 March 2018

\section{KEYWORDS}

Marx; critical discourse studies; ideology; critique; social suffering

If we understand ideology literally -that is as logics of ideas - and if we further understand this logic as an internal structure and ideas as expressed positions on a particular subject, then doing research on ideologies should not be too complicated. A simple content analysis of opinions about a specific subject will do. However, the notion of ideology, especially the one proposed by Marx in his critique of ideology is far more complex than a simple internal logic of expressed opinions. In the Marxist tradition the notion of ideology is related to social and material reality and especially to the processes of social reproduction. 
This is true in a triple sense: first, the concern for ideas is related to the explication of the role of ideas and convictions in processes of social reproduction. The world of ideas cannot be abstracted from material reality but can effect it in important ways. Second, in this tradition ideas are furthermore seen as a result of or at least as heavily influenced by social conditions. Here, the analysis of ideologies can reveal the unnoticed influences of the material reality on our thinking, which is therefore not as autonomous as we often believe or claim (see Stahl, 2015, p. 239). This leads us to our third point: ideologies have social functions and are therefore related to powerful social interests. Ideologies contribute to the stabilization of certain conditions and relations of domination.

Conceived in this way, the analysis of ideology seems to fall into the domain of discourse analysis. The analysis of language and practices of signification in social contexts constitutes the basic triangle of discourse analysis (Angermuller, Maingeneau, \& Wodak, 2014 , p. 7). Thus, it seems, discourse analysis not only investigates the internal structure of expressed ideas but relates this structure to practices and conditions in just the way the Marxist notion of ideology promotes. On the one hand, language use takes place in practices and conditions. On the other hand, language is able to condition practices and material realities. The very idea of an order of discourse as stated in Foucault's famous hypothesis is based on the relation between language and materiality. His hypothesis is 'that in every society the production of discourse is at once controlled, selected, organised and redistributed by a certain number of procedures whose role is to ward off its powers and dangers, to gain mastery over its chance events, to evade its ponderous, terrible materiality' (Foucault, 1981, p. 52, translation revised and italics B.H.). What is more, discourse analysis has to refer to materiality. If it fails to do so, it remains a simple decontextualized play of semantics (Hook, 2001, p. 542). Thus, conceptualizing language and power in their intimate relation is also part of the everyday work of discourse analysis.

The Marxist concept of ideology always refers to some kind of falsity. This ultimately enables the researcher to not only analyse but also to criticize ideologies. Ideologies are always in some way false, injust or inadequate. It is at this point that discourse analysts usually raise the most serious objections as they understand truth itself as a discursive product, resulting from powerful struggles of domination and exclusion. In what follows, I will to explore in how far the Marxist notion just outlined can be used for the purpose of discourse analysis. I will further argue that even the notion of falsity as present in classical Marxism can be adapted for understanding and criticizing contemporary ideologies.

I start by presenting some common understandings of ideology in the field of Discourse Studies (I). In a second step I will analyse elements of the notion of ideology in Marx's early writings, especially in the debate with the Young Hegelians (II) and ask what this means for empirical discourse analysis. I will then point towards elements of the critique of ideology in Marx mature 'political economy' that could be fruitful for Discourse Studies (III). Finally, I will try to reconcile a Marxist concept of ideology based ultimately on a notion of falsity with such discourse analytical approaches highly suspicious of the possibility of the existing 'politics of truth' (IV).

\section{Ideology in Discourse Analysis}

There is a vast body of literature about ideology in Discourse Analysis (see e.g. Beetz, 2016; Eagleton, 1991, Fairclough, 1992a, 1992b, 1995; van Dijk, 1999, 2006; Zienkowski, 2017). 
What is more, ideology seems to be one of the most 'natural' fields of discourse analysis. A very clear and typical theoretical introduction can be found in van Dijk (1999).

'... ideologies are the basic frameworks of organizing the social cognitions shared by members of social groups, organizations or institutions. In this respect, ideologies are both cognitive and social. They essentially function as the 'interface' between the cognitive representations and processes underlying discourse and action, on the one hand, and the societal position of interests of social groups, on the other hand. This conception of ideology also allows us to establish the crucial link between macrolevel analysis of groups, social formations and social structure, and microlevel studies of situated, individual interaction and discourse' (17 f.).

Although ideologies are usually expressed and reproduced in discourse, there are also other non-verbal forms of expression and reproduction of ideologies. These include nonverbal communication, such as pictures or gestures but also the embedding, materialisation and institutionalisation of ideologies in social contexts, organizations and institutions. Fairclough, following Althuser in his notion of ideology, states that ideology 'has a material existence in the practices of institutions, which opens up the way to investigate discursive practices as material forms of ideology' (Fairclough, 1992b, p. 87; in a similar way also Fairclough, 1995, p. 73). Furthermore, ideology constitutes subjects and are related to class struggle: 'ideological state apparatuses (institutions such as education or the media) are both sites of and stake in class struggle' (Fairclough, 1992b, p. 87). In other words, 'ideology has material effects, discourse contributes to the creation and constant recreation of the relations, subjects [...] and objects which populate the social world.' (Fairclough, 1995, p. 73).

This discursive and social approach should make it clear that in discourse analysis ideologies are not individual and conscious ideas but more of a 'basic frameworks of social cognition'. So for example a racist ideology includes 'knowledge' of economic relations, social threats, interpersonal relationships, international conflicts, etc. and they relate this knowledge to certain attitudes, e.g. with regard to migrants and normative claims about how the Social should be organized. Discourse analysis has developed very sophisticated tools to detect and describe these frameworks. The analysis of syntax, lexicon, local and global semantics, rhetoric, pragmatic, and interactional structures are just some of the analytic tools at our disposal.

As general abstract mental systems, ideologies are generally not linked to something like a 'false' consciousness in discourse analysis. What is more, van Dijk speaks of racist as well as of anti-racists, feminist, ecologist, communist, anti-communist, etc. ideologies (van Dijk, 1999, 2006). This leads us to a further problem: If it is true, that 'by definition these beliefs [...] lose their ideological nature as soon as they become part of the Common Ground' (van Dijk, 2006, p. 117), and he explicitly mentions Human Rights and gender equality in this context, then the way for critique is doubly closed. First, there seems to be no potential to utilize the concept of ideology for criticising discourses. The critical potential of such a discourse analysis has to be introduced from an external standpoint such as the already mentioned Human Rights. The criterion for critique then becomes mere legal 'injustice': 'As a criterion, we thus call any discourse unjust if it violates the internationally recognized human rights of people and contributes to social inequality' (van Dijk, 2009, p. 62). And second, there seems to be no possibility to criticize the Common Ground itself. It is not even ideological. If we give up the idea of 'falsity' in the 
concept of ideology, then the dedication to ideologies mainly becomes analysis of ideologies. Critique of ideology is only possible as external critique or as a denaturalization in the sense of a critical genealogy by demonstrating the social construction of realities.

Perhaps here, the somehow more critical notion of ideology brought forward by Norman Fairclough can help. For Fairclough, ideology is always related to power. As it could be argued that power is immanent to all social relations, there would be no social relation free of ideology. However, Fairclough decidedly refers to 'asymmetrical relations of power, to domination' (1995, p. 73) and especially to relations of 'of class, gender, cultural group, and so forth' (1992b, p. 91). What is important for Fairclough is that ideologies work unacknowledged or unconsciously and in everyday 'common sense' assumptions and practices. Especially institutionalized practices can be the embodiment of ideologies (see also Fairclough, 1992a, p. 78ff). And as the most common form of practice is language for him, the analysis of ideologies has to include the analysis of language use. Nevertheless, it is not very clear in his analysis of power and domination what he means when he writes that these practices 'originate' (Fairclough, 1989) in the dominant class or bloc. Is he insinuating that there are social groups who consciously create ideologies? And if so, are they doing so out of conviction or as conscientious imposture in order to maintain their power?

The notion of ideology of Fairclough seems to offer the potential of criticizing the ideology of the dominant class as they produce asymmetrical relations of power. Here we find the notion of critique similar to that of Foucault who understood critique as the 'art of not being governed or better, the art of not being governed like that' $(2007$, p. 44) and also as 'insubordination' or 'desubjugation' (p. 47). In these formulations, there is something negative (e.g. being governed in a certain way or subjugation) from which Foucault wanted to distance himself because he was suspicious of all existing - and particularly hegemonic - norms and values. However, in Foucault's and in Faircloughs's critique of power, it is not quite clear where that critical stance comes from. It seems that we are again trapped in an external form of critique of ideologies that criticises asymmetrical power structures because the authors themselves decide that they do not want to be governed like that.

In contrast, especially to van Dijks notion of ideology that only offers a way of analyising but not of critizising ideologies, in the Marxist tradition, the notion of ideology is always related to the critique of ideologies. Critique here refers to the conviction that ideologies are false, i.e. that they are a form of false consciousness. Additionally, this falseness does not only refer to a simple cognitive error. Rather, as ideas are (co-)produced by the conditions of social reproduction, it ultimately refers to a false reality. Ideologies can therefore be seen as necessarily false consciousness. This means that ideologies can even be the right expression of wrong social relations. As the ideas and ideological practices (re-)produce these social relations, they can be pernicious for those who reproduce ideologies. Falseness here means not only first order convictions but also second order beliefs about these convictions, i.e. the idea that the own beliefs are the objective truth, as not historically produced, as universal or as independent although they are not (see also Stahl, 2015, p. 239). This includes two important differences regarding the positivistic notion of ideology as is often used in the social sciences as well as discourse analysis: the Marxist notion not only describes a way of thinking related to a specific culture but 
criticises it as somehow false. Furthermore, such a critique always aims at a process of social change and is not just another interpretation of the world.

The question about truth and falsity is a very delicate one in Discourse Studies since we know that even truth is the result of a powerful social process. Taking truth as a criterion to criticise ideas seems to point towards the necessity to question our own process of truth creation. In an infinite regress we would then always question the position of the critic without ever coming to an end. For discourse analysis this ultimately refers to the need to rethink its notion of critique in Marxist terms (see Herzog, 2016).

The dilemma seems clear: Either we take an external point of view for our critique (e.g. our own conviction, the Bible or the Declaration of Human Rights). In this case, the critical, normative standpoint may not be adequate to the object of critique. My criteria may not be that of those criticised. Or we take take internal criteria of the object as our point of departure, i.e. of the subjects involved in the social process as criteria for normative critique. From this perspective it seems impossible to criticise certain false convictions as long as they are seen as correct for the individuals who hold them.

I propose that, instead, critique has to take an immanent position as a critique of the inadequacy of ideas as well as of social reality. This is, critique has to develop its criteria from within the object of analysis but has to be able to transcend its object. This is what is known as immanent critique (see Herzog, 2016; Romero, 2014; Stahl, 2013a, 2013b), i.e. in the words of Marx a form of critique that develops 'new principles for the world out of the world's own principle' (Marx, 1976, p. 345). The question in this case is: What normative sources do we have at our disposal for this type of critique? When talking about ideologies as somehow inadequate: in relation to what normative standard are they inadequate? What are the criteria that we can formulate normative judgements about the inadequacy or perniciousness of ideas and of social reality? (see also Jaeggi, 2014).

\section{Marx's critique of ideology for discourse analysts}

Although there is no coherent, singular theory of ideology in Marx's writings, we can understand ideology as set of convictions, attitudes, self-descriptions and conceptions about needs that have influence on the individual and collective actions of a society or of some social groups as well as the categorical forms in which individuals and collectives think and act (see Stahl, 2015; Jaeggi, 2009; Eagleton, 1991). Marx develops his critique of ideology first in relation to Hegel and then in discussion with the Young Hegelians although he seldom uses the word 'ideology'. The Young Hegelians preferred the term of 'critique of religion', using an expanded concept of 'religion', that ultimately refers to something we would now call ideology. However, in his critique of the critique of religion, Marx calls this critique of the Young Hegelians the 'German Ideology'. We could differentiate four disputes with the work of four authors whose outcome is relevant for our understanding of ideology with regard to discourse analysis: The debate with the work of the (then already dead) Hegel and with the Young Hegelians Ludwig Feuerbach, Bruno Bauer and Max Stirner.

(1) First of all we can find elements of a critique of ideology in Marx's analysis of the Hegelian philosophy. The main argument here referes to the way Hegel understands the relation between ideas and material reality. Following Marx's reading of Hegel, the 
latter understands the development of the 'Spirit' (Geist) as an independent factor in the development of society. For Marx, the relation has to be the other way round: History is made by real existing individuals who also produce ideas. Although here it seems that it is the material reality that produces Ideas, Marx, especially in his later writings was quite aware of the dialectical relation between ideas and materiality, stating for example that what differentiates the work of a bee from that of an architect is that the latter has an idea or plan before starting to work - but also admitting that it is the material reality that forces the architect to resolve material problems by planning (Marx, 1998, p. 193).

For discourse analysis, this Marxian critique of Hegel means that we should not think of the symbolic order of discourse, its textual or semantic character as an autonomous sphere but always relate it to the material reality it emerges in (see also Herzog, 2016). Although the very notion of discourse refers to something more than text and talk, i.e. to a material and practical infrastructure as well as to material and practical consequences of speaking and writing, especially in the more linguistic versions of discourse analysis the 'ponderous, terrible materiality' (Foucault) is seldom taken as explicit part of analysis. In other words: although the very notion of discourse implies the relation of words/ideas to material reality, in some discourse analyses text is treated as an independent unit of analysis.

(2) A second element of critique of ideology can be found in Marx's answer to the materialist position of Ludwig Feuerbach. For Feuerbach, religion is only apparently a theory about attributes and capacities of the divine. In reality it is a theory about human characteristics and capabilities. The critique of religion of Feuerbach, could thus be understood as critique of a process of projection. Humans project in divine entities those aspects of life that are especially important for their specific social and historical culture. For Feuerbach, religion is therefore the result of an intellectual alienation of humans and should be revised by a naturalistic world view that allows humans to recognize themselves.

Marx' critique here is that Feuerbach remains in the intellectual sphere in order to overcome religious or philosophical illusions. For Marx the origin of religion is not an intellectual alienation but an alienation that stems from social practices in which humans are unable to realize their essence. Critique therefore is not a critique of illusions but a critique of practical, material relations that produce these illusions (see also Marx, 1978, pp. 533-535).

If we follow this argument, then, this entails accounting for the social conditions of production of the discourses analysed. Discourses considered somehow ideological, false or inadequate should not be criticized internally by rational arguments. As they have their origin in a false reality it is reality that has to be changed. In this sense critique in critical Discourse Studies always refers to the critique of material, practical relations not to critique of discourses as simply false speech acts.

(3) Marx's critique of the early work of his mentor Bruno Bauer proceeds in a similar vein. However, what is of interest here is not so much Marx's critique to Bauer but the elements of Bauer's critique of religion that Marx incorporates in his own theory. We could even go as far as to say that Marx own notion of critique is highly influenced by Bauer's critique of religion. Bauer's argument can be summed up as follow: The Bible is a human product written by human authors. Especially with regard to the New Testament we know who these authors are (Matthew, Mark, Luke...). But although the Bible is a human product, it gains external power over humans as they forget about the human character and treat it at a somehow 'holy' text. This critique of production and reification 
can be found throughout Marx's entire work. The idea that humans produce their social relations but forget about the fact that these relations are human made is the basis of Marx's critique of reification and fetishization.

If we turn to discourses again, this critique of production and reification points towards the need to be aware of the fluid character as well as the historicity of material conditions, human relations, and discourses (see also Eagleton, 1991). They are all human made but simultaneously present themselves as an exterior force over us especially when we naturalize these phenomena. This is what Fairclough criticises when he talks about about 'common sense assumptions' or the naturalization of categories. In taking some ways of talking for granted, people exclude and protect these assumptions from rational critique. But for Marx it is about far more than only linguistic phenomena and ideas. It is about the forgetting of the man-made character of social relations and material reality. In relation to Foucault's mechanisms of the order of discourse, analysts should turn their view to the enormous material mechanisms and conditions that produce and shape discourses. Critique of ideology would then be the analysis of processes of production and reification of social relations and discourses in Foucault's sense of a critical genealogy.

(4) A forth moment of Marx's critique of ideology can be found in his debate with Max Stirner. Max Stirner, in his text 'The Ego and its Own', criticises the existence of religious assumptions in Feuerbachs concept of man [Mensch] (Stirner, 1995). 'Man' is still an abstract category in whose name violent intrusions in the life of individuals are justified. It makes no difference whether the individual is subjugated by the notion of God, the Nation, the State or the notion of mankind or humanity. We could think this argument a bit further and include other notions that actually legitimize impositions like truth, progress, democracy, reason and so on. All these generalized notions are transcendental categories, alien to the individual, to the Ego as Stirner names it, and should therefore be rejected. In a letter to Marx, Engels agrees with Stirners critique of Feuerbach: 'Stirner is right in rejecting Feuerbach's 'man', or at least the 'man' of Das Wesen des Christentums. Feuerbach deduces his 'man' from God, it is from God that he arrives at 'man', and hence 'man is crowned with a theological halo of abstraction.' (Engels, 1844). However, Marx in his (during his lifetime unpublished) extensive answer to Stirner, disagrees with the consequences of Stirners critique. The individual, Marx argues, is no original category either on which critique can rely. Individuals always find themselves already within social and material relations. It is not the effective reality of the individual that has to be the base for social critique but the effective reality of all existing social relations. This is ultimately an argument against the robinsonades as they could be found in some individual anarchist approaches but nowadays are mainly present in hegemonic economic theory that starts with a rational individual that is not bound socially in a significant way.

But there is also another important aspect for the critique of ideology expressed more clearly in Engels' letter to Marx. 'This egoism is simply the essence of present society and present man brought to consciousness' (Engels, 1844). ${ }^{1}$ Here we find the idea that wrong ideas can be right in the sense that they are the adequate reflection of 'false' social relations. In capitalist society people not only think they are individually isolated, capitalism treats them as isolated individuals. Therefore, the idea that critique has to start with the individual is adequate to the world of social isolation. The debate with Stirner is a good example to understand that all ideas and therefore also the ideology of Stirner has to be explained by social circumstances. Or, as Marx puts it in regard to Feuerbach: 
'The fog formations [Nebelbildungen] created in the human brain are also, necessarily, sublimates of their material life-process, which is empirically verifiable and bound to material premises.' (Marx, 1978, p. 26).

For discourse analysis this means that we, like Stirner, have to be aware of ideal mechanism that oppress the individuals in the name of some categories that seem to be out of scope of political debate and social influence. In this respect, Stirner can be seen as a precursor to Foucault and other poststructuralist thinkers that try to deconstruct current essentialisms (see also Newman, 2003). But Marx's critique towards Stirner reminds us that there is no 'pure' standpoint of critique, no place free of coercion, social influence and embeddedness in social and material relations. Trying no negate this embeddedness would not lead to an objective standpoint of critique but to an ideology of independence, autonomy and objectivity in discourse analysis. And finally, we can understand that ideologies are often adequate in the sense that they reflect the false social order in a right way.

Summing up our argument about ideology from the debate between the early Marx and the Young Hegelians for the purpose of discourse analysis we can say that, first, ideas and discourses are not autonomous formations, i.e. they do not exist independent of the social relations and have no unmediated power over these relations. Second, certain ideas or discourses can be both, true and false, at the same time. They can represent a certain wrong or pathological social structure in an appropriate way. Humans do not only feel alienated. They are alienated in the current society. And third, critique of ideology cannot be a merely cognitive task. It has to become practical. Or, as Marx said: 'Philosophers only have interpreted the world in various ways; the point is to change it' (1978, p. 535). In that sense, ideology as well as critique of ideologies is not something that only refers to the symbolic order of discourses but that has clearly a material part, including social relations, material reality and practices.

The problem now is: If ideologies are false, from an external point of view, but adequate from an internal point of view, what puts us in the position to be able to criticize ideology? This is again the question: how is our own standpoint of critique justified?

\section{Ideology and economic theory}

Already in the debates with the Young Hegelians Marx starts building his economic argument on ideology although he pushes it further in his mature writings. In the German Ideology we can find the argument that ideologies are related to the division of labour. At the very moment when intellectual and material work are divided 'consciousness can really flatter itself that it is something other than consciousness of existing practice' (Marx, 1978, p. 31). His alternative view of a communist society seems nowadays further away than ever. For Marx, at this point, a communist society is a society, 'where nobody has one exclusive sphere of activity but each can become accomplished in any branch he wishes, society regulates the general production and thus makes it possible for me to do one thing today and another tomorrow, to hunt in the morning, fish in the afternoon, rear cattle in the evening, criticise after dinner, just as I have a mind, without ever becoming hunter, fisherman, herdsman or critic' (Marx, 1978, p.37).

If we take this argument serious, as discourse analysts who find themselves in current societies, where the division of labour has grown to a dimension unimagined by Marx, we 
cannot expect alienation and ideology stemming from that division to be abolished. We can only be reflexive about this moment of social reproduction and take into account that our own work belongs to the intellectual side of social reproduction. And we further have to take into account that no single researcher has a full grasp of the complex interplay of material and intellectual work.

What is more, for Marx, the division of labour leads to a division of interests. What is brought into play here is a new model of the critique of ideology, the critique that ideology is not only wrong, but serves specific interests. Generally speaking, these are the interests of the most powerful. Especially when it comes to processes of legitimation, the ruling class is obliged to present its interest as a general interest for the society as a whole. In this sense, ideologies are problematic because they represent a partial interest as if it were the general interest. In Marx it is not quite clear whether he understands the representations of the ruling class as an unconscious error of representation or whether he thinks that the false representation is a conscious deceit in order to mislead the oppressed. Either way, ideologies have a specific functionality in a system of domination. So, ideology can be a second order false consciousness in a triple way: the bearers of ideologies can be unaware of the social-historical embeddedness of their own ideas, they can be unconscious of the explanatory limitations, i.e. about the fact that ideas have no autonomous force to create realities, and finally they can be unaware of the particular character of their own ideas, understanding them as universal or 'natural' (see also Stahl, 2015).

It is this relation of ideology to domination which is most prominent in discourse analysis. Here, the critique of ideology becomes a critique of domination. The question pertaining to the idea that a particular ideology serves the interest of the ruling class is to analyse how these ideas are forced upon the oppressed. Is it only by linguistic repetition, e.g. through media, the educational system and other important agents of socialization or is there something in the material and practical organization of society that facilitates the spreading or even the emergence of these legitimizing and stabilizing ideas?

Another element of critique of ideology as critique of domination can be found in Marx' preface of the Critique of Political Economy where he makes the differentiation between structure and superstructure that had important and sometimes fatal consequences in the history of Marxist movements: 'The totality of these relations of production constitutes the economic structure of society, the real foundation, on which arises a legal and political superstructure and to which correspond definite forms of social consciousness.' (Marx, 1971 , p. 8). Marx understands 'the legal, political, religious, artistic or philosophic' (Marx, 1971) as ideological forms. Here it seems that all dominant ideas of a time are ideological. ${ }^{2}$ Does this also mean that all ideas are false in some way or is there a possibility for nonideological philosophical, political or artistic ideas to emerge within the capitalist society? To what degree can alternative ideas that do not form part of the process of domination be non-ideological?

It is in Capital, where Marx gives some further insight into the relation of material reality and false consciousness, although he does not develop an explicit critique of ideologies in the three volumes. Here, more than in any other writings, Marx adheres to the idea that an economic existence produces a specific appearance. Wealth, commodities or value 'present themselves' or 'appear' in specific forms and even seem to have characteristics typically adscribed to subjects. We can find here the Hegelian dialectics between 
essence and appearance. The appearance is not just a wrong image. It simultaneuously contains a clue to the understanding of the essence.

In Capital, Marx seems to abandon the way of a critique of ideology as domination in the sense of a false, legitimizing consciousness. Instead he follows the way of a more 'innocent' appropriate reflection of objective relations that are nevertheless deceptive. As we will see, this does not mean a renunciation of critique of ideology as critique of domination. But instead of direct legitimation of personal power this ideology strengthens the existing relations of domination in a far more complex way. Especially in the famous section on commodity fetishism, we can see the apparent autonomy of capital, value, and the commodity. But the very fact that Marx deconstructs the wrong appearance of that autonomy and that we or 'the political economy' do not anymore share that wrong appearance, seems to refute the idea that ideologies are necessarily false consciousness. We now have the correct consciousness about the character of capital, commodity and value thus the exploiting social relations do not necessarily lead to a wrong consciousness. What is more, not only do the social relations still exist after intellectually deconstructing the wrong appearance, but the very discourse about commodity, capital and value still falsely expresses this relation - and it does this notwithstanding our insights. We still speak of values of commodities as if the value were inside the commodity, knowing very well that there is no atom of exchange value in any commodity. Thus, the error has to be in the fact that our discourses are part of a social practice that we cannot abandon (Rehmann, 2008, p. 38). In other words, the critique of ideology becomes a critique of practical necessities. It is not a cognitive critique but a critique of domination: although people can be able to understand correctly social relations (as Marx does) they still coordinate their actions in a specific form that prevents them from treating social relations as relations created by themselves e.g. by changing them.

This leads us to an interesting problem for discourse analysis. Not only are discourse (in a non-deterministic way) produced by the social order. The organization of the social forces certain practices upon us that reproduce this social order even if our conciousness about the social order is able to see through its falsity. For instance, there is quite a lot of work on gendered and gendering discourses. But even if we widely acknowledge that gender roles are socially constructed, even when we change our way of speaking by using gender neutral terms, avoid stereotyping or try to create whole new forms of inclusive speaking - in our practices we are almost forced to relate to the binary distinction. We cannot even go to a public toilet without 'recognizing' our belonging to one of the two pre-established genders.

Discourse analysis and the critique of discourses therefore not only has to concentrate on the discourses itself and the practices that produce a certain discourse. Discourse analysis as a scientific practice has to be aware of the fact that there are power relations which can sometimes be seen in the language use but even continue to reproduce in certain practices that are not necessarily practices of discourse production. If we want to fully grasp ideologies in that way with discourse analysis this means treating practices even independently of its relation to the production of language. When we understand practices as meaningful, structured elements with a possible normative content, then we can analyse practices in a very similar way as we analyse language for discourse analytical purpose (on that point see Herzog, 2016). 


\section{Conclusion}

If we do not want to loose the possibility of critique of ideologies, i.e. a normative critique that aims to unmask the systematic falsity of certain ideas, then the reading of Marx can help draw our attention to certain notions of falsity of ideologies. We can now understand ideology as necessarily - i.e. systematically and socially produced and not abolishable within the given society - false consciousness or unconscious practices. Ideologies are embedded in necessarily false (discursive) practices and social organization and regarding to which we are only able to tell why it is false or inadequate in an immanent way. By evaluating ideas, practices and the material organization of society against societies' very own norm that suffering should not be (see, e.g. Adorno, 1970; Herzog, 2016, 2018; Honneth, 1992) we can finally solve, with this immanent approach, the conundrum of the question of truth and falsity. Ideologies are false because they systematically produce (or are part of a system that produces) social suffering. In other words: ideologies contravene societies own normative expectations that suffering should not be. Ideologies are then not false in an absolute sense but in the sense that they lead to, hide or justify what is not justified by society itself.

Due to the relation between ideas and material organization in ideologies, the critique of ideologies becomes not only a critique of practices of justifications but turns into a genuine social critique. A social order is than critizised because it systematically fails to fullfill its own normative claims. This final turn could reconcile the Marxist insistence on an ultimate (but relative) distinction between truth and falsity with an crititcal discourse analytical notion of ideology. We can understand that behind Foucault's will 'not to be governed like that' or behind Faircloughs mistrust towards power inequalities there is the unacknowledged norm that social suffering should not be and the suspicion that the actual way of being governed or of power distribution produces, hides or justifies precisely this suffering.

\section{Notes}

1. For the debate between Marx and Stirner see also E $\beta$ bach (1982).

2. However, in the very same text, Marx has to struggle with the question why, in capitalist societies, we still like Greek art, i.e. a superstructure that, following his theory is, part of a vanished relation of social reproduction.

\section{Disclosure statement}

No potential conflict of interest was reported by the authors.

\section{Notes on contributor}

Benno Herzog is Associate Professor at the Department of Sociology and Social Anthropology, University of Valencia, Spain. He has worked and conducted research in Germany (Universities of Frankfurt and Mainz), the United Kingdom (University of Manchester, Open University, and University of Warwick), and Brazil (Federal University of Paraíba). His research focuses on social critique and critical theory of society, discourse theory and discourse analysis, and migration and discrimination. 


\section{References}

Adorno, T. W. (1970). Negative Dialektik. Jargon der Eigentlichkeit. FrankfurtMain: Suhrkamp.

Angermuller, J., Maingeneau, D., \& Wodak, R. (2014). The discourse studies reader - An introduction. In J. Angermuller, D. Maingeneau, \& R. Wodak (Eds.), The discourse studies reader (pp. 1-14). Amsterdam: John Benjamins.

Beetz, J. (2016). Materiality and subject in Marxism, (Post-)structuralism, and material semitotics. London: Palgrave.

Eagleton, T. (1991). Ideology. An introduction. London: Verso.

Eßbach, W. (1982). Gegenzüge. Der Materialismus des Selbst und seine Ausgrenzung aus dem Marxismus. Frankfurt a.M.: Materialis.

Engels, F. (1844). Letter to Karl Marx, November 1844. Retrieved from https://www.marxists.org/ archive/marx/works/download/Marx_Engels_Correspondence.pdf

Fairclough, N. (1992a). Language and power. London: Longman.

Fairclough, N. (1992b). Discourse and social change. Cambridge: Polity Press).

Fairclough, N. (1995). Critical discourse analysis. London: Longman.

Foucault, M. (1981). The order of discourse. In R. Young (Ed.), Untying the text: A post-structural anthology (pp. 48-78). Boston, MA: Routledge \& Kegan Paul.

Foucault, M. (2007). The politics of truth. Los Angeles: Semiotext(e).

Herzog, B. (2016). Discourse analysis as social critique. Discursive and non-discursive realities in critical social research. London: Palgrave.

Herzog, B. (2018). Suffering as an anchor of critique. The place of critique in critical discourse studies. Critical Discourse Studies, 15(2), 111-122.

Honneth, A. (1992). Der Kampf um Anerkennung. Zur moralischen Grammatik sozialer Konflikte. Franfkurt: Suhrkamp.

Hook, D. (2001). Discourse, knowledge, materiality, history - Foucault and discourse analysis. Theory \& Psychology, 11(4), 521-547.

Jaeggi, R. (2009). Was ist Ideologiekritik? In R. Jaeggi \& T. Wesche (Eds.), Was ist Kritik? (pp. 268-295). Frankfurt a.M.: Suhrkamp.

Jaeggi, R. (2014). Kritik von Lebensformen. Berlin: Suhrkamp.

Marx, K. (1971). Werke (Vol. 13). Berlin: Dietz.

Marx, K. (1976). Werke (Vol. 1). Berlin: Dietz.

Marx, K. (1978). Werke (Vol. 3). Berlin: Dietz.

Marx, K. (1998). Werke (Vol. 23). Berlin: Dietz.

Newman, S. (2003). Stirner and Foucault: Toward a Post-Kantian Freedom. Postmodern Culture, 13(2). Retrieved from http://muse.jhu.edu/journals/postmodern_culture/v013/13.2newman.html

Rehmann, J. (2008). Einführung in die Ideologietheorie. Hamburg: Argument.

Romero, J. M. (2014). Immanente Kritik heute. Zur Aktualität eines sozialphilosophischen Begriffes. Bielefeld: transcript.

Stahl, T. (2013a). Habermas and the project of immanent critique. Constellations, 20(4), 533-552.

Stahl, T. (2013b). Immanente Kritik. Elemente einer Theorie sozialer Praktiken. Frankfurt M: Campus.

Stahl, T. (2015). Ideologiekritik. In M. Quante \& D. Schweikard (Eds.), Marx-Handbuch (pp. 238-252). Stuttgart: Metzler.

Stirner, M. (1995). The Ego and Its Own. Cambridge: University Press.

van Dijk, T. (1999). Discourse analysis as ideology analysis. In A. Wenden \& C. Schäffner (Eds.), Language and peace (pp. 17-33). Amsterdam: Harwood Academic.

van Dijk, T. (2006). Ideology and discourse analysis. Journal of Political Ideologies, 11(2), 115-140.

van Dijk, T. (2009). Critical discourse studies: A sociocognitive approach. In R. Wodak \& M. Meyer (Eds.), Methods for critical discourse analysis (pp. 62-85). London: Sage.

Zienkowski, J. (2017). Articulations of self and politics in activist discourse. A discourse analysis of critical subjectivities in minority debates. Cham: Palgrave Macmillan. 